Jurnal Warta Lembaga Pengabdian pada Masyarakat

Vol. 22, No. 2, September 2019, hlm. 67-75

p-ISSN: 1410-9344; e-ISSN: 2549-5631

homepage: http://journals.ums.ac.id/index.php/warta

\title{
PENINGKATAN KOMPETENSI SISWA MELALUI PEMBINAAN OLIMPIADE SAINS (OSN)
}

\author{
${ }^{1}$ Tri Wiyoko, ${ }^{2}$ Megawati, ${ }^{3}$ Aprizan, ${ }^{4}$ Nurlev Avana \\ Program Studi Guru Sekolah Dasar, STKIP Muhammadiyah Muara Bungo \\ Email: 1yokostkipmb@gmail.com, ${ }^{2}$ mega.uqi@gmail.com, ${ }^{3}$ apriiizan87@gmail.com, \\ ${ }^{4}$ avananurlev10@gmail.com
}

\begin{abstract}
ABSTRAK
Pengembangan sumber daya manusia yang berkualitas harus dilakukan sejak dini. Adanya kegiatan OSN IPA akan memberikan gambaran atau pemataan kemampuan siswa di sekolah. Adapun tujuan pembinaan OSN IPA antara lain 1) Meningkatkan pengetahuan siswa SD dalam bidang sains, 2) Meningkatkan keterampilan siswa SD dalam menyelesaikan soal-soal olimpiade sains, 3) Meningkatkan kemampuan analisis siswa dalam menyelesaikan soal-soal olimpiade sains. Pembinaan dilaksanakan dengan 3 tahapan yaitu 1) Perencanaan, 2) Pelaksanaan, dan 3) Evaluasi. Tahap perencanaan meliputi pengumpulan dan mereduksi soal OSN tahun sebelumnya. Tahap pelaksanaan meliputi proses pembinaan dengan menerapkan proses pembelajaran melalui diskusi, tanya jawab, Focus Group Discussion (FGD). Tahap Evaluasi dilakukan dengan memberikan soal OSN untuk mengevaluasi kemampuan siswa. Hasil pembinaan Olimpiade Sains (OSN) di SD Negeri 102/Sei.Kerjan memberikan pengaruh yang baik untuk persiapan OSN siswa di tahun 2019. Selama proses pembinaan siswa aktif, antusias dan semangat. Hasil yang diperoleh selama pembinaan yaitu siswa yang pengetahuannya bertambah secara signifikan sebesar $40 \%$ atau 4 orang, siswa yang memiliki kemampuan keterampilan menyelesaikan soal-soal sebesar $30 \%$ atau 3 orang dan kemampuan menganalisis soal sebesar $20 \%$ atau 2 orang.
\end{abstract}

Keyword: Kompetensi, OSN, Pengetahuan, Keterampilan, Analisis

\begin{abstract}
Development of quality human resources must be done early. The existence of OSN IPA activities will provide an overview or even distribution of students' abilities at school. The aims of developing the Natural Sciences OSN include: 1) Increasing elementary students' knowledge in science, 2) Improving elementary students' skills in solving science olympics questions, 3) Improving students' analytical skills in solving science olympics questions. Coaching is carried out in 3 stages, namely 1) Planning, 2) Implementation, and 3) Evaluation. The planning stage includes gathering and reducing the previous year's OSN questions. The implementation phase includes the coaching process by implementing the learning process through discussion, question and answer, Focus Group Discussion (FGD) The Evaluation Phase is carried out by providing OSN questions to evaluate students' abilities. The results of coaching the Science Olympiad (OSN) at SD Negeri 102 / Sei. Kerjan gave a good influence on the preparation of OSN students in 2019. During the process of coaching students were active, enthusiastic and enthusiastic. The results obtained during coaching are students whose knowledge has increased significantly by 40\% or 4 people, students
\end{abstract}


Wiyoko, dkk. - Peningkatan Kompetensi Siswa Melalui ...

who have the ability to solve problems by $30 \%$ or 3 people and the ability to analyze questions by $20 \%$ or 2 people.

Keyword: Competence, OSN, Knowledge, Skills, Analysis

\section{PENDAHULUAN}

Pengembangan kualitas Sumber Daya Manusia harus dilakukan sejak dini. Mengingat kemajuan negara bergantung akan kualitas sumber daya manusia yang ada. Sumber daya manusia sendiri tidak terlepas dari pendidikan, karena dengan pendidikan akan meningkatkan kemampuan daya nalar, kreativitas dan berpikir kritis sehingga dapat menjadikan manusia untuk siap bersaing. Kemampuan tersebut penting untuk ditingkatkan terutama pada abad 21 ini. Kemampuan berpikir tingkat tinggi perlu latih sejak siswa duduk di kelas SD, karena siswa sebagai generasi penerus bangsa harus menjadi pemikir-pemikir yang kritis, jujur dan bermartabat, sehingga mampu menghadapi berbagai tantangan dan dapat bertahan hidup secara manusiawi dengan penuh rasa percaya diri (Hasratuddin, 2010)

Pemerintah dalam rangka peningkatan kualitas sumber daya manusia dalam aspek pendidikan salah satunya dilakukan dengan mengadakan Olimpiade Sains Nasional tingkat SD/MI (OSN-SD/MI) dan atau yang sederajat telah dirintis sejak tahun 2003. Program ini merupakan salah satu wadah strategis untuk mengembangkan daya nalar, kemampuan memecahkan masalah, kreativitas, dan sportivitas siswa. Pelaksanaan OSN-SD secara berkelanjutan akan berdampak positif pada peningkatan mutu pendidikan dan pembelajaran sehingga siswa memiliki daya juang yang tinggi, kompetitif dan inovatif. Upaya yang dilakukan oleh pemerintah dalam jangka panjang tersebut seharusnya di respon dengan baik oleh instansi/ lembaga pendidikan. Tetapi tidak semua pihak mempersiapkan diri untuk menghadapi OSN, biasanya sekolah hanya mengajukan siswa yang memiliki prestasi belajar yang baik saja.

OSN merupakan salah satu upaya menguatkan mutu pendidikan di jenjang sekolah dasar, karena pendidikan dasar merupakan fondasi yang sangat baik dan penting untuk melanjutkan di jenjang yang lebih tinggi. Upaya penguatan fondasi tersebut harus dilakukan dengan mengubah orientasi pendidikan yang berorientasi pada siswa. Sehingga siswa akan aktif dalam proses pembelajaran. Salah satu indikator peningkatan mutu pada suatu jenjang pendidikan adalah meningkatnya kemampuan siswa dalam hal kemampuan berpikir kritis, daya nalar, kreativitas, sikap, dan budi pekerti siswa.

Kemampuan siswa di Indonesia dalam bidang sains, masih kategori rendah meski mengalami peningkatan dari tahun sebelumnya. Performa sains siswa Indonesia masih berada di peringkat ke 4 di Asia Tenggara. Data PISA tahun 2015 disajikan pada Tabel 1.

Tabel 1. Rata-Rata Performa Sains

\begin{tabular}{cc}
\hline Negara & Skor \\
\hline Singapura & 556 \\
Vietnam & 525 \\
Thailand & 421 \\
Indonesia & 403 \\
\hline \multicolumn{2}{c}{ (Sumber:PISA 2015) }
\end{tabular}

Berdasarkan data Tabel 1, menandakan sudah seharusnya pendidikan di Indonesia untuk melakukan pembenahan sejak dini agar ke depannya performasains siswa di Indonesia dapat semakin meningkat. Performa sains terbentuk dengan baik, apabila proses pembelajaran di dalam kelas dilaksanakan dengan menerapkan pembelajaran yang sainstifik. Kemudian hasil pembelajaran dapat terukur dengan melibatkan siswa dalam kompetisi OSN. Oleh karena itu, pembinaan OSN IPA dapat dimanfaatkan untuk memperbaiki performa sains siswa Indonesia. Selain itu, Pembinaan OSN ini dapat menjadi sarana untuk memperbaiki Litersi sains untuk siswa yang sekolah di daerah. Literasi sains sangat diperlukan dalam pendidikan, akan tetapi penilaian dari Program for International Student Assessment (PISA) menunjukkan bahwa pencapaian siswa-siswi Indonesia untuk sains, membaca, dan matematika masih menempati 
peringkat 62, 61, dan 63 dari 69 negera. Artinya Literasi sains siswa di Indonesia masih tergolong rendah.

Adanya Kegiatan OSN IPA akan memberikan gambaran atau pemataan kemampuan siswa di sekolah. Sehingga sekolah-sekolah yang mengikutkan siswa dalam OSN akan dapat mengevaluasi dirinya seberapa tinggi kemampuan siswa di dalam mengerjakan soalsoal OSN. Hal ini dapat menjadi gambaran kualitas atau mutu sekolah tersebut. Sehingga hasil OSN dapat menjadi acuan oleh kepala sekolah untuk meningkatkan proses pembelajaran IPA di sekolah yang di pimpin.

Sekolah Dasar Negeri 102/ Sei. Kerjan merupakan salah satu sekolah di kabupaten Muara Bungo dengan status akreditasi B. Pada tahun akademik 2017/2018 sekolah ini memiliki rombongan belajar sebanyak 17 rombongan belajar dengan seluruh total siswanya sebanyak 468 orang. SD Negeri 102/Sei. Kerja selama ini telah ikut berpartisipasi aktif dalam kegiatan OSN. Pihak sekolah telah mengikutkan siswanya untuk kompetensi OSN setiap tahunnya. Pada Tahun 2018 ada 1 siswa yang mewakili sekolah untuk lolos pada tingkat kecamatan, akan tetapi gagal pada seleksi untuk tingkat kabupaten.

Pada tahun akademik 2018/2019 sekolah akan tetap mengirimkan siswanya untuk mengikuti OSN 2019. Oleh karena itu perlu adanya persiapan sejak dini untuk mengikuti kegiatan tersebut. Siswa harus banyak berlatih dalam mengerjakan soal-soal yang berkaitan dengan sains, karena tingkat kesulitan soal-soal dalam OSN termasuk ke dalam soal jenis C3-C6. Hal ini tentu perlu dilatihkan kepada siswa agar dapat lolos pada tahapan-tahapan selanjutnya. Soal OSN sendiri memiliki tingkat kesulitan yang tinggi dan kompleks. Sehingga benar-benar menguji kemampuan siswa dalam bidang IPA.

Pembinaan OSN IPA merupakan Program Pengabdian kepada Masyarakat (PkM) yang dilaksanakan dalam wujud pembinaan kepada siswa di SD Negeri 102/ Sei Kerjan kabupaten Muara Bungo Propinsi Jambi. Hasil wawancara dengan kepala sekolah di dapatkan bahwa siswa di SD Negeri 102/ Sei. Kerjan kurang banyak berlatih dalam mengerjakan soal-soal OSN, karena belum banyak memiliki kolesi soal OSN tahun-tahun sebelumnya. Selain itu, proses pembelajaran IPA di SD hanya terbatas pada buku panduan untuk siswa dan guru. Belum adanya pendalaman materi IPA di dalam aktivitas belajar di kelas. Sehingga kemampuan siswa dalam kompetisi OSN masih kurang. Oleh karena itu, pembinaan siswa untuk dapat berkompetensi di OSN sangat dibutuhkan.

Pembinaan OSN ini ditujukan kepada siswa SD Negeri 102/Sei. Kerjan. Peserta yang mengikuti pembinaan ini akan di persiapkan untuk mengikuti OSN tahun 2019 di tingkat kecamatan. Apabila siswa lolos seleksi maka akan maju di tingkat kabupaten, propinsi dan nasional. Melalui pembinaan ini siswa mendapatkan latihan soal-soal yang menuntut kemampuan berpikir tingkat tinggi mulai dari berpikir kritis, menganalisis, daya nalar, dan kreativitas. Program pembinaan OSN ini, sejalan untuk mendukung penerapan K-13 di sekolah yang proses pembelajarannya dengan menggunakan metode Scientific Approach (Evi Fussalam, 2018: 55). Sehingga kurikulum tahun 2013 sejalan untuk menghasilkan siswa-siswa yang berkualitas agar dapat menyelesaikan soalsoal OSN yang memiliki tingkat kesulitan tinggi untuk siswa SD.

Adapun tujuan yang hendak di capai dalam pengabdian pembinaan OSN ini adalah sebagai berikut;

a. Meningkatkan pengetahuan siswa SD dalam bidang sains

b. Meningkatkan keterampilan siswa SD dalam menyelesaikan soal-soal olimpiade sains.

c. Meningkatkan kemampuan siswa dalam menganalisis soal-soal olimpiade sains.

\section{METODE PELAKSANAAN}

Pelaksanaan kegiatan ini di khususkan siswa/siswi yang dipersiapkan oleh pihak sekolah untuk mengikuti olimpiade sains. Pelaksanaan pembinaan di SD Negeri 102/Sei. Kerjan Kabupaten Muara Bungo pada tanggal 30 Januari -12 Februari 2019. Waktu pelaksanaan di luar jam sekolah atau setelah siswa pulang sekolah sampai sore hari.

Adapun langkah-langkah kegiatan yang dilakukan adalah:

a. Kegiatan pembinaan Olimpiade Sains (OSN) diawali dengan persiapan mengumpulkan

Warta LPM, Vol. 22, No. 2, September 2019 
soal-soal olimpiade tingkat SD dalam kurun 5 tahun terakhir. Kemudian menyeleksi/ mereduksi soal-soal OSN tersebut apakah masih relevan dengan bidang ilmu pada buku panduan OSN.

b. Kegiatan pembinaan Olimpiade Sains (OSN) dalam pelaksanaannya meliputi: pengerjaan soal secara diskusi dan tanya jawab, pembahasan secara bersama-sama, Focus Group Discussion (FGD) dan penjelasan oleh pembina untuk materi-materi yang tidak dipahami oleh siswa.

c. Kegiatan pembinaan Olimpiade Sains bagian akhir yaitu evaluasi, meliputi; penilaian kemajuan siswa dalam hal pemahaman, keterampilan penyelesaian soal dan kemampuan analisis.

Teknik yang digunakan untuk mengetahui tingkat pemahaman, keterampilan penyelesaian soal dan kemampuan analisis siswa berdasarkan test. Soal test yang diberikan ke siswa merupakan soal-soal OSN yang dipilih dari beberapa soal OSN tahun sebelumnya. Tipe soal yang diberikan merupakan soal objektif atau pilihan ganda yang disertai alasan jawaban.

Setelah siswa menyelesaikan pengerjaan soal, maka perlu diadakan analisis perkembangan/kemajuan siswa dengan teknik kategori siswa berdasarkan Tabel 1.

Tabel 2. Persentase Kemajuan Siswa

\begin{tabular}{cc}
\hline Kriteria & Persentase \\
\hline Sangat tinggi & $80 \%<\mathrm{P} \leq 100 \%$ \\
Tinggi & $60 \%<\mathrm{P} \leq 80 \%$ \\
sedang & $40 \%<\mathrm{p} \leq 60 \%$ \\
Rendah & $20 \%<\mathrm{P} \leq 40 \%$ \\
Sangat rendah & $0 \%<\mathrm{P} \leq 20 \%$ \\
\hline
\end{tabular}

(Junaidi, 2017: 20)

Data yang telah dikelompokkan berdasarkan tabel, akan dianalisis secara deskriptif.

\section{HASIL DAN PEMBAHASAN}

Pembinaan Olimpiade Sains (OSN) dilaksanakan sebagi bentuk wujud kepedulian dosen-dosen PGSD STKIP Muhammadiyah Bungo terhadap prestasi siswa/siswi di sekitar kabupaten Muara Bungo. Pembinaan dilaksanakan dengan tujuan untuk (1) meningkatkan pengetahuan siswa SD dalam bidang sains, (2) meningkatkan keterampilan siswa SD dalam menyelesaikan soal-soal olimpiade sains, (3) meningkatkan kemampuan menganalisis siswa dalam menyelesaikan soalsoal olimpiade sains.

Pembinaan dilaksanakan di SD Negeri 102/ Sei Kerjan Kabupaten Muara Bungo. Siswa yang mengikuti pembinaan ini sebanyak 10 orang yang berasal dari kelas 4 dan kelas 5 . Proses pembinaan meliputi tahapan-tahapan: persiapan, pelaksanaan dan evaluasi.

Tahap Pertama, Persiapan dalam pembinaan olimpiade sains yang dilakukan dengan mengumpulkan dan menyeleksi soalsoal OSN setingkat Sekolah Dasar. Soal-soal yang dikumpulkan yaitu dalam kurun waktu 5 tahun terakhir mulai dari tahun 2014 sampai dengan tahun 2018. Kemudian soal seleksi kembali untuk dikelompokkan dengan bidang ilmu sains yang meliputi; Keterampilan dan metode ilmiah; 1) Pengklasifikasian makhluk hidup berdasarkan makanan, anatomi, sistematik, dan habitat; 2) Proses dan mekanisme yang terjadi pada makhluk hidup (manusia, hewan, tumbuhan, dan mikroorganisme); 3) Interaksi organisme dengan lingkungan dan informasi mengenai hewan langka; 4) Isu, perkembangan dan permasalahan umum tentang kesehatan, lingkungan dan teknologi; 5) Mekanika, yang mencakup gerak benda, gaya, momentum, energi mekanik, dan fluida; 6) Wujud benda, yang mencakup sifat dan kegunaan benda padat, benda cair, dan gas; 7) Listrik dan Kemagnetan, yang mencakup listrik statis, listrik dinamis, sifat magnet, dan induksi elektromagnetik; 8) Gelombang dan Optik, yang mencakup gelombang tali, bunyi, sifat-sifat gelombang, cahaya, gelombang elektromagnetik, dan alat optik (cermin, lensa, dan aplikasinya); 9) Suhu dan panas, yang mencakup skala suhu, termometer, dan hantaran panas; 10) Energi dan perubahannya, yang mencakup energi panas, energi bunyi, energi terbarukan, konversi energi, dan aplikasinya; 11) Struktur Atom, yang mencakup inti atom dan elektron; 12) Bumi, Tata surya, dan Galaksi: struktur bumi, atmosfer bumi, proses terbentuknya planet, struktur planet, iklim, rotasi dan revolusi benda langit, 
bintang dan galaksi (Kemendikbud, 2018: 2122)

Selanjutnya dilakukan pembagian dengan dosen sebagai pengampu dari materi-materi tersebut.

Tahap kedua, pelaksanaan pembinaan OSN. Proses pembinaan OSN dilaksanakan pada tanggal 30 Januari sampai 12 Februari 2019. Pelaksanaan secara teknis sebagai berikut; 1) siswa diberikan fotocopy kumpulan soal-soal OSN. 2) Siswa diberikan kesempatan untuk mengerjakan soal no 1-10 dalam waktu 15 menit secara individu, 3) Pembina membimbing siswa untuk menjawab soal-soal yang sulit di jawab oleh siswa, 4) Pembahasan jawaban setiap soal secara bersama-sama. Pada kegiatan ini, instruktur memberikan pendalaman materi yang terkait dengan soal tersebut. Pendalaman materi yang diberikan kepada siswa diutamakan pada materi-materi yang sulit untuk di pahami oleh siswa, karena materi tersebut baru pertama kali diperoleh. Tetapi tidak semua materi diberikan pendalaman, apabila setiap soal diberikan pendalaman materi, maka waktu pelatihan yang tersedia tidak mencukupi.

Adanya diskusi dan pendalaman materi sangat membantu siswa dalam memahami dan menjawab soal-soal OSN IPA. Siswa memperoleh pengalaman dan pengetahuan yang baru. Hal ini sejalan dengan penelitian Susana (2017) terdapat pengaruh signifikan penerapan metode diskusi terhadap kemampuan berpikir kritis peserta didik. Pengaruh penerapan metode diskusi terhadap kemampuan berpikir kritis dapat dibuktikan dengan perhitungan t-test yang dilakukan pada skor angket kelas eksperimen dan kelas kontrol.

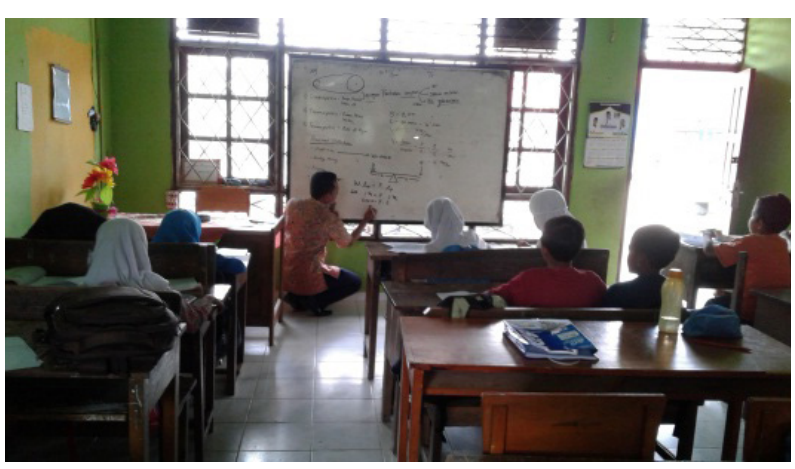

Gambar 1. Diskusi dan Pendalaman Materi

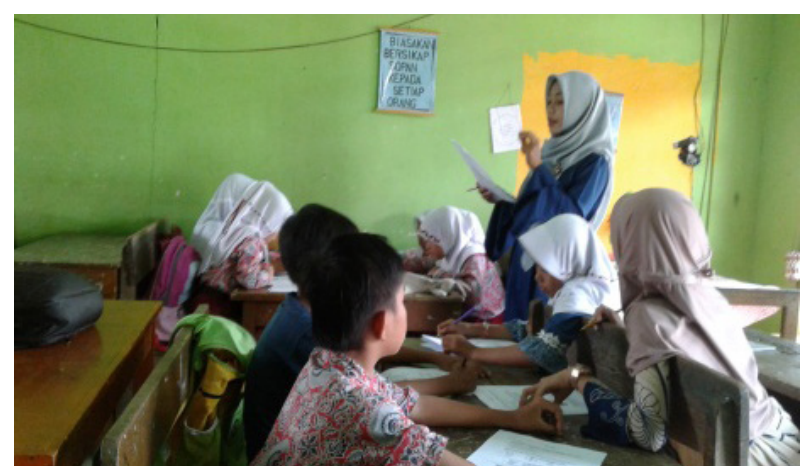

Gambar 2. Forum Diskusi Grup

Setelah Pengerjaan dan pembahasan soal nomor 1-10 selesai, maka siswa diminta untuk mengerjakan soal di nomor selanjutnya. Model kegiatan diskusi dan tanya jawab ini berlangsung selama pertemuan I dan II. Sedangkan untuk pertemuan ke III dan IV dilaksanakan dengan menerapkan Focus Group Discussion (FGD).

Model Focus Group Discussion (FGD) dimaksudkan agar siswa tidak jenuh, maka perlu adanya variasi dalam pelaksanaan pembinaan OSN. Selain itu, melalui kegiatan Focus Group Discussion (FGD) mampu meningkatkan kemampuan dan keterampilan dalam pembelajaran (Siregar, 2018).

Pertemuan ke III dan IV dilaksanakan dengan langkah sebagai berikut; 1) Siswa dibagi menjadi dua kelompok, 2) Siswa diminta untuk mendiskusikan soal-soal OSN tahun 2015 pertemuan ke III dan soal -soal OSN tahun 2016, 3) pembina dan siswa membahas soal-soal yang telah dikerjakan secara bersama-sama. 4) pembina memberikan konfirmasi jawaban serta memberikan pendalaman materi yang sedang di bahas. Pada pertemuan ke III dan IV ini, soal-soal yang diberikan lebih banyak pada soal fisika, sehingga proses latihan untuk mengerjakan soal memakan waktu yang banyak.

Selanjutnya untuk tahapan pertemuan ke V dan VI dilaksanakan secara terpadu yaitu diskusi, tanya jawab serta forum diskusi grup. Selama penerapan pendekatan di atas, siswa ada yang mengalami perkembangan yang baik, tetapi ada sebagian siswa yang sedang-sedang saja. Kemudian siswa rata-rata mengalami kesulitan pada soal-soal yang menggunakan bahasa inggris. Meskipun ada kendala dalam soal bahasa inggris, tetapi untuk soal yang berbahasa Indonesia siswa sudah mulai mampu 
untuk mengungkapkan argumentasinya ketika memilih jawaban dari soal-soal OSN.

Adanya pembinaan OSN ini dapat memberikan dampak yang baik untuk pengetahuan siswa. pada umumnya siswa SD yang awalnya hanya mengetahui materi-materi untuk tingkat SD kemudian menjadi bertambah pengetahuannya setingkat materi SMP. Selain itu, pelatihan ini dapat meningkatkan literasi Sains dan melatih skill argumentasi siswa. Secara persentase pengetahuan siswa disajikan pada Grafik 1.

Berdasarkan Grafik 1, dinyatakan bahwa siswa yang yang memiliki pemahaman materi yang tinggi sebanyak $40 \%$ atau 4 siswa dari 10 siswa. Kemudian siswa yang memiliki pemahaman yang sedang sebanyak $20 \%$ atau 2 siswa dan tingkat pemahaman yang rendah sebesar $40 \%$ atau sebanyak 4 siswa. Perbedaan tingkat pemahaman siswa disebabkan karena siswa yang ikut pelatihan ini berasal dari jenjang kelas yang berbeda. Sehingga siswa yang kelas tinggi akan memiliki pemahaman yang lebih tinggi karena pernah memperoleh materi yang dipelajari walaupun tidak mendalam. Sedangkan siswa yang berasal dari kelas 4, memiliki pemahaman yang sedang dan rendah. Sebagaimana penelitian Agustini, (2017: 42) bahwa siswa yang memiliki pengetahuan awal yang kurang, akan menjadikan tahapan untuk berpikir tingkat tinggi pun kurang. Selain itu, penjelasan yang diberikan oleh instruktur juga memberikan pengaruh kepada pemahaman siswa. Sebagaimana penelitian Utomo (2017:1 ) bahwa ketika penjelasan guru baik maka akan berbanding lurus dengan pemahaman siswa yang baik, sehingga ada pengaruh penjelasan guru terhadap pemahaman siswa.

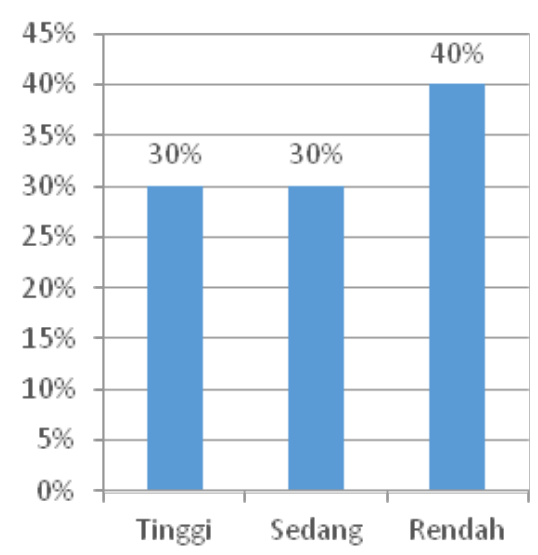

Gambar 3. Tingkat Pemahaman Siswa
Selanjutnya untuk keterampilan siswa, Keterampilan siswa harus dilatih sejak dini, karena siswa sebagai bagian dari generasi abad 21 harus mampu menghadapi tantangan permasalahan kehidupan yang dinamis dan menuntut kreativitas (Redhana, 2019: 2241) Menurut National Education Association (n.d.) bahwa keterampilan abad ke-21 meliputi berpikir kritis, kreativitas, komunikasi, dan kolaborasi.

Siswa yang terlibat dalam OSN harus mampu mengadopsi keterampilan abad 21 tersebut, salah satunya di dalam menyelesaikan soal-soal OSN dapat di lihat dari kemampuan siswa di dalam menemukan jawaban yang di sertai dengan alasanalasan yang mendukung jawaban tersebut. Hal ini dimaksudkan untuk memperbanyak literasi sains. Apabila siswa memiliki literasi sains yang baik, maka siswa akan dapat memberikan argumentasi terhadap jawabannya dengan baik. karena terdapat pengaruh linier yang positif dan signifikan skill argumentasi terhadap hasil belajar siswa (Agusni, 2017: 97)

Adapun hasil pembinaan OSN dalam keterampilan menyelesaikan soal-soal disajikan pada Grafik 2.

Pada Grafik 2 menunjukkan bahwa siswa yang memiliki keterampilan tinggi sebanyak $30 \%$ atau 3 orang. Selanjutnya untuk yang sedang sebesar $30 \%$ atau 3 orang serta siswa yang rendah sebanyak $40 \%$ atau 4 orang. Siswa yang memiliki keterampilan yang tinggi di lihat dari keruntutan di dalam menuliskan penyelesaian atau jawaban serta jawabannya benar. Kemudian siswa yang kategorinya sedang, belum mampu untuk menuliskan jawaban secara runtut tetapi memiliki kemampuan menjawab dengan benar serta siswa yang kategori rendah belum mampu untuk menuliskan jawaban dengan benar. Salah satu penyebab rendahya kemampuan siswa untuk dapat menyelesaikan persoalan runtut yaitu kurangnya pengelolaan guru di kelas sehingga menjadikan siswa tidak berperan aktif dalam kegiatan pembelajaran, akibatnya siswa kurang mampu untuk berpikir secara kritis, baik serta logis (Susanti, 2018: 800). 


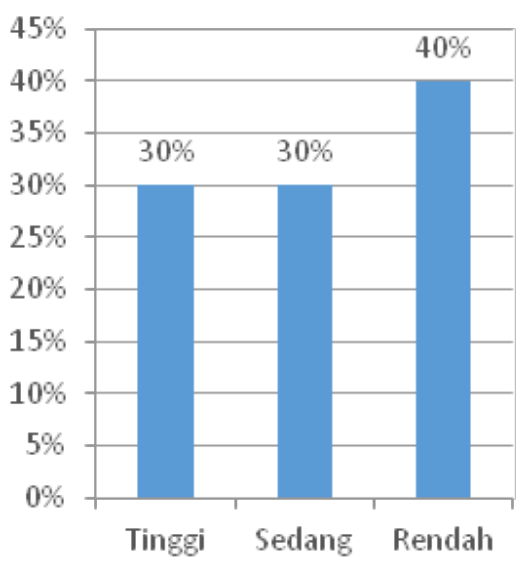

Gambar 4. Keterampilan Menyelesaikan Soal

Adanya aktivitas belajar yang membiasakan kepada siswa untuk menjawab pertanyaan dengan runtut dan benar akan melatih skill siswa ketika mengikuti kompetensi OSN. Menjawab pertanyaan yang runtut akan membangun kemampuan berpikir logis. Sebagaimana menurut Murraya (2011) bahwa untuk menumbuhkan kemampuan berpikir tingkat tinggi pada diri siswa, membutuhkan suasana pembelajaran yang mendukung dan juga guru yang membantu perkembangan siswa dengan cara menyiapkan materi pembelajaran dan tugas-tugas yang melibatkan siswa secara aktif dalam bernalar dan berpikir logis.

Kemampuan siswa yang terakhir yaitu kemampuan di dalam menganalisis untuk menjawab pertanyaan. Kemampuan siswa di dalam menganalisis pertanyaan-pertanyaan di dalam pembinaan rata-rata masih kesulitan. Hanya ada beberapa siswa yang memiliki kemampuan menganalisisyang baik. kemampuan menganalisis sangat penting dikarenakan bagian dari membentuk kemampuan siswa untuk berpikir tingkat tinggi. Menganalisis merupakan proses yang melibatkan proses memecahmecah materi menjadi bagian-bagian kecil dan menentukan bagaimana hubungan antara bagian dan antara setiap bagian dan struktur keseluruhannya. Kategori proses menganalisis meliputi proses-proses kognitif membedakan, mengorganisasi, dan mengatribusikan (Winarti, 2015: 21).

Hasil kemampuan siswa di dalam menganalisis disajikan pada Grafik 3.

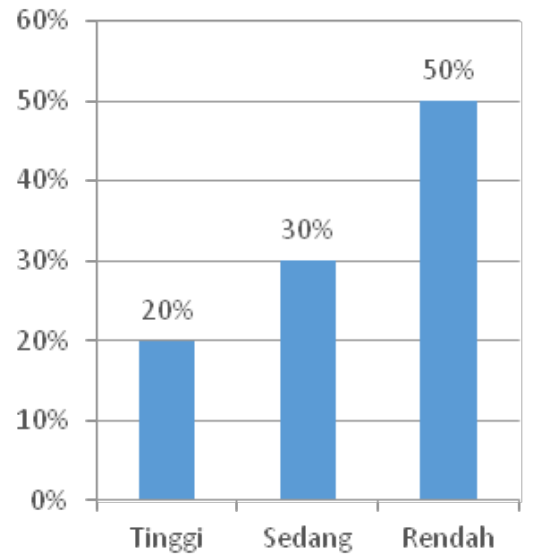

Gambar 5. Kemampuan Menganalisis Siswa

Berdasarkan Grafik 3 diperoleh bahwa kemampuan siswa yang baik di dalam menganalisis sebesar $20 \%$ atau 2 orang. Kemudian siswa yang sedang $30 \%$ atau 3 orang serta siswa yang rendah $50 \%$ atau 5 orang. Siswa yang memiliki kemampuan menganalisis yang baik akan memiliki pemahaman yang baik juga serta keterampilan yang baik pula di dalam menyelesaikan pertanyaan. Hal ini sejalan dengan hasil penelitian Alatas (2014) bahwa adanya hubungan kemampuan pemahaman konsep dengan keterampilan berpikir kritis yang di dalamnya termasuk dalam komponen menganalisis.

Selain itu dengan adanya pembinaan OSN IPA ini memberikan pengaruh yang baik kepada siswa. Informasi yang diperoleh dari wawancara dengan guru menunjukkan bahwa siswa yang telah mengikuti pembinaan memiliki semangat kerja keras dan terlihat kompetitif di dalam proses pembelajaran. Siswa sudah mulai mampu untuk sedikit berargumentasi dan literasi sains siswa mulai bertambah. pembelajaran literasi sains penting bagi siswa untuk memahami apa yang dipelajari. Literasi sains dapat dijadikan acuan untuk mengembangkan pembelajaran IPA karena literasi sains dinilai efektif dalam mengembangkan pembelajaran IPA di abad 21 (Pertiwi, 2018:28). Selain itu, kajian Kurniawati (2014) bahwa siswa yang mengikuti pembinaan OSN mengalami peningkatan wawasan pengetahuan, kemampuan, kreativitas dan kerja keras untuk menguasai ilmu pengetahuan. Serta pemberian soal OSN secara open ended akan melatih kemampuan siswa untuk berpikir kreatif (Hidayat, 2018: 78)

Warta LPM, Vol. 22, No. 2, September 2019 
Dengan demikian kegiatan OSN IPA yang telah dilaksanakan memberikan pembekalan yang baik untuk siswa baik dari aspek pengetahuan, keterampilan dan menganalisis.

\section{SIMPULAN}

Pelaksanaan Pembinaan Olimpiade Sains (OSN) di SD Negeri 102/Sei.Kerjan memberikan pengaruh yang baik untuk persiapan OSN siswa di tahun 2019. Selama proses pembinaan siswa aktif, antusias dan semangat. Pelaksanaan kegiatan pembinaan terbagi menjadi tiga tahapan yaitu persiapan, pelaksanaan dan evaluasi. Hasil yang diperoleh selama pembinaan yaitu meningkatnya pengetahuan siswa secara signifikan sebesar $40 \%$ atau 4 orang, siswa yang memiliki kemampuan keterampilan menyelesaikan soal-soal sebesar 30\% atau 3 orang dan kemampuan menganalisis soal sebesar $20 \%$ atau 2 orang.

Berdasarkan pengabdian yang telah dilaksanakan maka perlu adanya program pengabdian OSN yang berkelanjutan. Hal ini dimaksudkan agar pembinaan untuk calon-calon peserta OSN akan semakin siap untuk mengikuti seleksi. Kemudian memperbanyak koleksikoleksi soal OSN dan berlatih untuk mengerjakan baik secara mandiri maupun dengan guru. Selanjutnya perlu adanya pembinaanpembinaan yang serupa di sekolah yang lain agar dapat menumbuhkan jiwa yang siap berkompetisi dalam bidang sains. bagi bapak/ ibu guru sebaiknya memulai pembinaan OSN sedini mungkin melalui proses pembelajaran di dalam kelas

\section{PERSANTUNAN}

Terima kasih kepada seluruh tim pelaksana pengabdian yang telah merencanakan, melaksanakan mengevaluasi dan menyusun laporan pengabdian. Kemudian kepada ketua Lembaga Pengembangan Penelitian dan Pengabdian Masyarakat (LP3M) Sekolah Tinggi Keguruan dan Ilmu Pendidikan Muhammadiyah Muara Bungo yang telah memberikan penugasan dan izin pelaksanaan pengabdian. Selanjutnya kepada kepala sekolah SD Negeri 102/II Sei. Kerjan atas kerjasamannya pelaksanaan pengabdian peningkatan kompetensi siswa melalui pembinaan Olimpiade Sains (OSN).

\section{DAFTAR PUSTAKA}

Agustini, Fitria dan Sopandi, Wahyu Peningkatan Kemampuan Bertanya Dan Penguasaan Konsep IPAMelalui Pendekatan Question Formulation Technique (QFT). Jurnal Penelitian Pendidikan. Vol 17, No 1 Tahun 2017 Hal 35-44

Agusni Hendika Prasetyo, Abdurrahman \& Wahyudi, Ismu. 2017. Pengaruh Skill Argumentasi Menggunakan Model Problem Based Learning Terhadap Hasil Belajar Siswa. Jurnal Pembelajaran Fisika. Vol 5, No 4 Tahun 2017 hal 97-104

Alatas, Fathiah. 2014. Hubungan Pemahaman Konsep Dengan Keterampilan Berpikir Kritis Melalui Model Pembelajaran Treffinger Pada Mata Kuliah Fisika Dasar. EDUSAINS. Vol VI No 1 Tahun 2014 hal 88-96.

Evi Fussalam, Yahfenel dan Elmiati. 2018. Implementasi Kurikulum 2013 (K13) SMP Negeri 2 Sarolangun. Jurnal Muara Pendidikan Vol. 3 No. 1 Tahun 2018 hal 45-55

Hasratuddin. 2010. Meningkatkan Kemampuan Berpikir Kritis Siswa SMP Melalui Pendekatan Matematika Realistik. Universitas Negeri Medan. Jurnal Pendidikan Matematika. Vol 4 No 2 Desember 2010 hal 19-33.

Hidayat, Puput Wahyu dan Abdulah 2018. Pengaruh Pendekatan Ctl Dengan Soal Open Ended Terhadap Kemampuan Berpikir Kreatif Mahasiswa. Jurnal Muara Pendidikan Vol. 3 No. 1 Tahun 2018 hal 78-91

http://sekolah.data.kemdikbud.go.id/index.php/chome/profil/20445f5c-0c26-e111-bbd2$752 \mathrm{~b} 4 \mathrm{f} 713 \mathrm{f} 23$ 
Junaidi. 2017. Analisis Kemampuan Berpikir Kritis Matematika Siswa Dengan Menggunakan Graded Response Models Di SMA Negeri 1 Sakti. Jurnal Prodi Pendidikan Matematika FKIP Universitas Jabal Ghafur Sigli. Volume 4. Nomor 1. April 2017 hal 14-25

Kemendikbud. 2018. Petunjuk Teknis Olimpiade Sains Nasional Sekolah Dasar Tahun 2018. Jakarta: Direktorat Pembinaan Sekolah Dasar, Direktorat Jenderal Pendidikan Dasar dan Menengah

Kurniawati, Maris. 2014. Kajian Motivasi Belajar Mandiri Siswa Melalui Pembinaan dan Pendampingan Olimpiade Sains Nasional (OSN) Bidang Kimia pada Siswa SMA. Jurnal Inspirasi Pendidikan Universitas Kanjuruhan Malang. Vol 4 No 1 Januari 2014 hal 446-455.

National Education Association. (n.d.).Preparing 21stCentury Students for a Global Society: An Educator's Guide to the "Four Cs." www.nea.org diakses 26 September 2019

Murraya, E. C. (2011). Implementing Higher-Order Thinking in Middle School Mathematics Classrooms. Disertasi. Georgia: University of Georgia.

OECD. 2018. PISA 2015 Result and Focus.

OECD-PISA. 2004. Learning for Tomorrow's World. USA: OECD-PISA.

Pertiwi, Utami Dian., Dwik Atanti, Rina \& Ismawati,R. Pentingnya Literasi Sains Pada Pembelajaran Ipa Smp Abad 21. Indonesian Journal of Natural Science Education (IJNSE). Volume 01, Nomor 01, 2018 hal 24-29

Redhana, I Wayan. 2019. Mengembangkan Keterampilan Abad Ke-21 Dalam Pembelajaran Kimia. Jurnal Inovasi Pendidikan Kimia, Vol 13, No 1, Tahun 2019 hal 2239-2253

Siregar, Syafaruddin. 2018. Meningkatkan Kemampuan Guru Dalam Menerapkan Pembelajaran Kontekstual Melalui Focus Group Discussion (FGD) DI SMK Negeri 1 Sirandorung Tahun Pelajaran 2017/2018. Nusantara (Jurnal Ilmu Pengetahuan Sosial) Vol 5 Oktober 2018 hal 14-19.

Susan, Dewi Vita \& Suyato. 2017. Pengaruh Penerapan Metode Diskusi Terhadap Kemampuan Berpikir Kritis Peserta Didik Pada Mata Pelajaran Pendidikan Pancasila Dan Kewarganegaraan Di Madrasah Tsanawiyah Negeri Karangmojo. Jurnal Pendidikan Kewaraganegaraan dan Hukum. Vol 6 No 4 Tahun 2017 Hal 512-521.

Susanti, Tri, Pujiastusi, Emi \& Suparsih, Harni. 2018. Optimalisasi Kemampuan Berpikir Logis Dan Percaya Diri Peserta Didik Kelas. PRISMA I (Prosiding Seminar Nasional Matematika) Tahun 2018 hal 800-804.

Utomo, Agung Aditya, Ali Imron, \& Syaiful M. 2017. Pengaruh Penjelasan Guru Terhadap Pemahaman Siswa pada Mata Pelajaran Sejarah. PESAGI (Jurnal Pendidikan dan Penelitian Sejarah) Vol 5, No 8 Tahun 2017 Hal 1-12

Winarti, 2015. Profil Kemampuan Berpikir Analisis Dan Evaluasi Mahasiswa Dalam Mengerjakan Soal Konsep Kalor. Jurnal Inovasi Dan Pembelajaran Fisika, Volume 2, Nomor 1, Mei 2015 hal 19-24 